\title{
Knowledge and Practices of Menstrual Hygiene among Married Adolescents and Young Women in Chittoor District Of Andra Pradesh: India
}

\author{
Dr. Patil Sudha Rani
}

\begin{abstract}
Background: Adolescent girls often lack knowledge regarding reproductive health including menstruation which can be due to socio-cultural barriers in which they grow up. The menstrual hygiene related practices of female in the adolescence period can have effect on their health. Issues associated with menstruation are never discussed openly and this burdens adolescent girls by keeping them ignorant of this biological function. Among the various sub groups of women, reproductive health of married adolescence and young women is of crucial and especially in a state like Andhra Pradesh.
\end{abstract}

Aims and Objectives: To assess the knowledge and practices of menstrual hygiene among married adolescent and young women.

Methods and materials:The present study was conducted among 400 married adolescent and young women who are in the age group of 15-25 years, residing in Tirupati division, Chittoor district, Andhra Pradesh. A community based cross sectional study was conducted in 4 mandals of tirupati division. The subjects were selected randomly from the eligible couple registers available with the health workers. The interview technique was used to collect the data with the help of pre-designed, pre-tested questioner prepared by the investigator. Results : The average of the respondent is 19.6 years and average age at menarchy was 13.2 years. The mean scours of respondents' menstrual hygiene is observed to be significantly $(p<0.01)$ very high among those who belong to nuclear families than among those from joint families. It is further, conspicuous to note that the differences in mean scores of menstrual hygiene across respondents' and spouses' level of educational attainment turn out to be highly significant ( $p<0.01$ and $p<0.01$, respectively). level of menstrual hygiene appear to be increasing (significant at moderate level; $p<0.05$ ) with an increase in time spent on watching TV / listening to radio. It is also interesting to note that the average level of menstrual hygiene of those respondents who marred their blood relatives is found to be higher (and moderately significant; $p<0.05$ ) than those who married with non-blood relatives. On the other hand, the mean score of menstrual hygiene appear to be marginally lower among those who are adhering to large number of restrictions during menstruation than those who are following small number of such restrictions.

Conclusion: Many factors are known to affect menstrual hygiene along with education and occupation of married adolescent/young woman and her spouse. There is a need of adolescent girls to get adequate information about healthy menstrual practices. The medical health care personal have to organize village level/urban slum level meetings/camps to interact with married adolescent and young women to increase their awareness on menstrual hygiene. Most of the adolescent and young women were not consumed balanced diet due to food restrictions and taboos during menstruation. Hence, it is suggested to conduct extensive nutrition educational programmes along with health education by the health functionaries.

Keywords: Menstruation, Menstrual Hygiene, Married adolescence, Married Young women

\section{Introduction}

Adolescence is a significant period in the life of a woman that requires specific and special attention. This period is marked with onset of menarche. Adolescent girls often lack knowledge regarding reproductive health including menstruation which can be due to socio-cultural barriers in which they grow up. The World Health Organization has defined adolescence as the period between 10-19 years of life they constitute about $1 / 5^{\text {th }}$ total female population in the world.

Menarche is defined as "Commencement of Menstrual periods and occurrence of bodily changes" (Roper, Pocket Medical Dictionary, 1981). Menarche is a developmental milestone in the life of women and most of their activities are closely monitored and at times even restricted. Menstruation is generally considered as unclean in the Indian society. Isolation of the menstruating girls and restrictions being imposed on them in the family, have reinforced a negative attitude towards this phenomenon. The menstrual hygiene related practices of female in the adolescence period can have effect on their health. The first menstruation is often horrifying and traumatic to an adolescent girl because it usually occurs without her knowing about it. Women having a better knowledge regarding menstrual hygiene and safe menstrual practices are less vulnerable to reproductive tract infections and its consequences. 
Issues associated with menstruation are never discussed openly and this burdens adolescence girls by keeping them ignorant of this biological function. Good menstrual hygiene is crucial for the health, education, and dignity of girls and women. This is an important sanitation issue which has long been in the closet and still there is a long standing need to openly discuss it. Studies that dealt with menstrual hygienic practices in a composite manner and its determinants found to be very limited. Majority of these studies focused on unmarried adolescent girls rather than married adolescents and young women. Among the various sub groups of women reproductive health of married adolescent and young women is of crucial and especially in a state like Andhra Pradesh. The state is well known for early marriages of girl/women.

\section{OBJECTIVES}

- To assess the knowledge and practices of menstrual hygiene among married adolescents and young women.

- To understand the role of socioeconomic and cultural practices influencing on menstrual hygiene.

\section{Methods And Materials}

The present study was under taken among 400 married adolescent and young women who are in the age group of 15-25 years and residing in Tirupati division, Chittoor district, Andhra Pradesh. A community based cross sectional study was conducted in 4 mandals of Tirupati division viz., Tirupati Rural, Chandragiri, Renigunta and Pakala, have been selected randomly. A sample of 100 respondents from each selected Mandal was selected from the eligible couple registers available with the health workers. A pre-designed, pre-tested questionear was administered on subjects to collect the data by using interview technique at their residence. The questionnaire included topics related to awareness about menstruation, sources of information, hygiene and food practices during menstruation.

\section{Demographic and background characteristics/ respondents}

1.1 Age: Among the sample women, majority (37\%) of the respondents are in the age group of 18-19 years, whereas slightly more than one-fourth of them are in the ages of 22 years and above. While 21 percent are in the age group of 20-21 years, 18 percent are in very young ages (15-17 years). The average age of the respondents is 19.6 years.

1.2 Age at marriage: Among the southern states of India, Andhra Pradesh is well known for its lower age at marriage for girls to some extent in the case of boys too. In the case of sample women, majority got married at the age of 17-18 years (44.3\%), whereas another sizeable proportion (35\%) of women got married at very young age (14-16 years). Rest of them entered into married life at the ages of 19-20 years and 21 years and above. The average age at marriage of the sample women is 17.4 years

1.3 Total Members in the Family: In the case of respondents' families, as high as 65 percent of them have 35 members only. On the other hand, slightly more than one-fifth of the families have (6-8) members whereas few of them (7.5\%) have large number of members ( 9 and more) in their families. Just 5 percent of the respondents have only 2 members in their families.

1.4 Religion: Among the sample respondents, about 84 per cent are adhering to Hinduism and 14.5 per cent to Islam. Only 5 respondents belong to Christianity. Majority of the sample women belong to backward castes (38\%), closely followed by forward castes (30\%), whereas about one-fifth of them belong to Scheduled caste/tribes and the rest one-sixth are from most backward castes.

1.5 Caste: Majority of the sample women belong to Backward Castes (38\%), closely followed by Forward castes (30\%), whereas about one-fifth of them belong to Scheduled Caste/Tribes and the rest one-sixth are from Most Backward Castes

1.6 Educational status of the respondents: Slightly less than 30 per cent are illiterates and another onefourth of them are educated up to primary school level, while 18 per cent of the respondents are just literates but could not complete primary school, about one-sixth of them able to complete middle school level of education. Slightly one-tenth of the women studied up to high/higher secondary school level, whereas just 6 per cent of them could able to complete collegiate education.

1.7 Educational status of the spouses: about 18 per cent of the spouses are educated up to middle school, closely followed by primary school level and high/higher secondary school level. On the other hand, about one-sixth of them are just literates, but could able to complete primary school.

1.8 Occupational status of the respondents: A greater proportion (85.5\%) of the respondents is reported to be homemakers. About 8 per cent of the respondents engaged in the agricultural labour and another 4 percent as cultivators.

1.9 Occupational status of the spouses: Among the sample respondents, slightly more than one-third of the spouses are working as employees in the Government and Private Establishments, closely followed by 
agricultural labourers (33\%). While 18 per cent of the spouses reported to be cultivators, one-tenth of them are skilled/semi-skilled workers or engaged in own (petty) business. Very few spouses are not working.

1.10 Place of Birth: As high as three-fourths of the respondents born and brought up in rural areas and the rest of them born and brought up in urban areas

1.11 Type of family: In the sample population, around two-thirds of the respondents belong to nuclear family (one couple with or without children as well as unmarried / widowed / divorced relatives) and the remaining respondents belong to joint families

1.12 Major Medium of Communication: about half of them the major communication channels are Television or Radio, whereas for about 11 per cent of them News paper / magazines and for some telephone is the only major channel of communication. Interestingly, for about 28 per cent of the respondents Telephone / Post \& Telegraph / Television/Radio are the major medium of communication and a few are exposed to all the types of communicational channels under consideration.

1.13 Time Spent on Watching TV/Listening to Radio: a simple majority reported that they use to spend about 2 hours or less per day, whereas about 31 per cent each stated that they use to spend 3 hours and 4 or more hours for such an activity.

1.14 Type of Programme Preferred to Watch/Listen Mostly: Revealed for slightly less than half of the respondents serials (soap operas) are the most preferred programmes in TV. On the other hand, around one-fourth each of them stated that cinema (movies) and songs (song sequences from movies) are the most preferred TV programmes for them.

1.15 Marriage with a Blood Relative: In the past, marriages with blood relatives were most common in southern states of India, especially in Andhra Pradesh, Karnataka and Tamil Nadu. But in the recent past, the prevalence of such marriages has been reduced in many communities of these states. When the respondents are being enquired about this, slightly less than one-fourth of them got married a blood relative and the rest higher percent of them stated that they got married a non-blood relative. This reduced trend in consanguineous marriage is mainly because most of the people are aware of the consanguineous of such marriages.

1.16 Type of Relationship: When the details of those married with a blood relative were inquired among the total sample respondents, the proportion of marriages with maternal uncle stated to be the higher in number $(12 \%)$, whereas the cross-cousin marriages (marrying mother's brother's son and father's sister's son) are somewhat less ( $8 \%$ and $4 \%$, respectively).

\begin{tabular}{|c|c|c|}
\hline Demographic and background characterstics & Percentage & Number \\
\hline \multicolumn{3}{|l|}{1.1 Age of the Respondent (in Years) } \\
\hline $15-17$ & 18.3 & 73 \\
\hline $18-19$ & 37.3 & 149 \\
\hline $20-21$ & 20.8 & 83 \\
\hline $22+$ & 25.8 & 95 \\
\hline \multicolumn{3}{|l|}{ 1.2 Age at Marriage of the Respondent (in Yrs.) } \\
\hline $14-16$ & 35.0 & 140 \\
\hline $17-18$ & 44.3 & 177 \\
\hline $19-20$ & 17.5 & 70 \\
\hline $21+$ & 3.2 & 13 \\
\hline \multicolumn{3}{|l|}{1.3 Total Members in the Family } \\
\hline$\leq 2$ & 5.0 & 20 \\
\hline $3-5$ & 65.0 & 260 \\
\hline $6-8$ & 22.5 & 90 \\
\hline $9+$ & 7.5 & 30 \\
\hline \multicolumn{3}{|l|}{1.4 Religion } \\
\hline Hindu & 84.3 & 337 \\
\hline Muslim & 14.5 & 58 \\
\hline Christian & 1.3 & 5 \\
\hline \multicolumn{3}{|l|}{ 1.5 Caste } \\
\hline Scheduled Castes / Tribes & 19.8 & 79 \\
\hline Most Backward Castes & 12.5 & 50 \\
\hline Backward Castes & 37.5 & 150 \\
\hline Forward Castes & 30.3 & 121 \\
\hline \multicolumn{3}{|l|}{ 1.6 Educational Status of the Respondent } \\
\hline Illiterate & 28.5 & 114 \\
\hline Literate & 17.5 & 70 \\
\hline Primary School & 23.8 & 95 \\
\hline Middle School & 15.5 & 62 \\
\hline High School and Higher Secondary & 9.0 & 36 \\
\hline Degree (including Professional) and above & 5.8 & 23 \\
\hline $\begin{array}{l}\text { 1.7 Educational Status of the Spouse } \\
\text { Illiterate }\end{array}$ & 20.0 & 80 \\
\hline
\end{tabular}




\begin{tabular}{|c|c|c|}
\hline $\begin{array}{l}\text { Literate } \\
\text { Primary School } \\
\text { Middle School } \\
\text { High School and Higher Secondary } \\
\text { Degree (including Professional) and above }\end{array}$ & $\begin{array}{l}12.8 \\
15.0 \\
18.2 \\
13.0 \\
21.0\end{array}$ & $\begin{array}{l}51 \\
60 \\
73 \\
52 \\
84\end{array}$ \\
\hline $\begin{array}{l}\text { 1.8 Occupational Status of the Respondent } \\
\text { Housewives } \\
\text { Agriculture Labourers } \\
\text { Cultivators } \\
\text { Skilled / Semi-skilled / Petty Business } \\
\text { Employees (Government and Private) } \\
\end{array}$ & $\begin{array}{l}85.5 \\
7.5 \\
3.8 \\
0.8 \\
2.5\end{array}$ & $\begin{array}{l}342 \\
30 \\
15 \\
3 \\
10\end{array}$ \\
\hline $\begin{array}{l}\text { 1.9 Occupational Status of the Spouse } \\
\text { Not Working / Unemployed } \\
\text { Agriculture Labourers } \\
\text { Cultivators } \\
\text { Skilled / Semi-skilled and Petty Business } \\
\text { Employees (Govt. and Private) / Others }\end{array}$ & $\begin{array}{l}4.0 \\
32.8 \\
18.0 \\
10.8 \\
34.5\end{array}$ & $\begin{array}{l}16 \\
131 \\
72 \\
43 \\
138\end{array}$ \\
\hline $\begin{array}{l}\text { 1.10 Place of Birth } \\
\text { Rural } \\
\text { Urban } \\
\end{array}$ & $\begin{array}{r}74.8 \\
25.2 \\
\end{array}$ & $\begin{array}{l}299 \\
101 \\
\end{array}$ \\
\hline $\begin{array}{l}\text { 1.11 Type of family } \\
\text { Nuclear Family } \\
\text { Joint Family }\end{array}$ & $\begin{array}{l}65.5 \\
34.5 \\
\end{array}$ & $\begin{array}{l}262 \\
138 \\
\end{array}$ \\
\hline $\begin{array}{l}\text { 1.12 Major Medium of Communication } \\
\text { Telephone } \\
\text { Television / Radio } \\
\text { News Paper / Magazines } \\
\text { Telephone / Post \& Telegraph / } \\
\text { Television / Radio } \\
\text { All the above }\end{array}$ & $\begin{array}{l}7.8 \\
49.8 \\
10.5 \\
28.2 \\
3.8\end{array}$ & $\begin{array}{l}31 \\
199 \\
42 \\
113 \\
15\end{array}$ \\
\hline $\begin{array}{l}\text { 1.13 Time Spent on Watching TV/ } \\
\text { Listening to Radio } \\
\leq 2 \text { hours } \\
3 \\
4+\text { hours }\end{array}$ & $\begin{array}{l}37.5 \\
31.3 \\
31.3\end{array}$ & $\begin{array}{l}150 \\
125 \\
125\end{array}$ \\
\hline $\begin{array}{l}\text { 1.14 Type of Programme Preferred to } \\
\text { Watch/Listen Mostly } \\
\text { Songs } \\
\text { Cinema } \\
\text { Serials } \\
\end{array}$ & $\begin{array}{l}25.7 \\
26.8 \\
47.5\end{array}$ & $\begin{array}{l}103 \\
107 \\
190\end{array}$ \\
\hline $\begin{array}{l}\text { 1.15 Married a Blood Relative } \\
\text { Yes } \\
\text { No }\end{array}$ & $\begin{array}{l}23.8 \\
76.3 \\
\end{array}$ & $\begin{array}{l}95 \\
305 \\
\end{array}$ \\
\hline $\begin{array}{l}\text { 1.16 Type of Relationship } \\
\text { Not Married a Blood Relative } \\
\text { Maternal Uncle } \\
\text { Mother's Brother's Son } \\
\text { Father's Sister Son }\end{array}$ & $\begin{array}{l}76.3 \\
12.0 \\
7.5 \\
4.3\end{array}$ & $\begin{array}{l}305 \\
48 \\
30 \\
17\end{array}$ \\
\hline
\end{tabular}

\section{Menstruation and related aspects}

In the present study, majority (38\%) of the married adolescents and young women attained their first menarche at the age of 13 years, closely followed by 14 years and one-fifth at the age of 12 years. On the other hand, some respondents $(8.3 \%)$ attained their first menarche at the age of 15 years, whereas very few $(2.8 \%)$ attained menstruation of the first time at the age of 11 years or after. The average age at menarche of the sample respondents is 13.2 years. When enquired about this aspect among sample women, about half (49.3\%) of them stated that menarche is 'shedding blood from vagina on regular intervals', whereas two-fifths (39.3\%) of them reported it as a 'normal process or phenomenon among women'. And remaining (11.5\%) of married adolescence felt that it 'indicates that woman is eligible for reproduction'. A simple majority (36.3\%) of the respondents stated that they use the word 'mensus' closely followed by 'muttu' and 'date'. Few married adolescence (8.5\%) call it 'bahistu' and very few (4.5\%) as 'periods'. A sizeable percent of the respondents (13.8\%) stated that they learn about menstruation through 'class text books/teacher' and just about 4.5 per cent told that they had such knowledge through mass media. 31.5 per cent of the respondents through family members and remaining 13.8 per cent of the respondents were learned through magazines were friends.

When the respondents enquired that anybody explained about menarche to them, as high as 71 per cent stated that they were not told about menarche or menstruation before its first experience, whereas the rest of them $(29.2 \%)$ told that they had been explained about menstruation and related aspects at least in a nutshell form by one or the other persons. As high as 75 percent of the married adolescents and young women appear to be little bold enough so as inform to their mother about the onset of first menarche, whereas about one-fifth of the 
respondents reported to be frightened at their onset of first menstruation. While very few 'felt it as dirty' and 5 respondents even concealed about it from others for some days. Among the sample respondents, more than three-fourths (76\%) stated that they use to get menstruation at regular intervals and the remaining felt that their menstrual cycles are somewhat irregular. Slightly more than half of them (53\%) reported that their menstrual cycles use to be mostly within the range of $25-28$ days and another sizeable proportion of them $(38.3 \%)$ mentioned that their menstrual cycles use to be 29-30 days. Curiously, about 6 percent each of them stated that their length of menstrual cycles would be within 25 days and or more than 30 days.

Among the sample respondents, majority reported that the shedding of menstrual blood would be 5 days to them closely followed by 4 days. In the case of slightly more than one-tenth of the respondents the duration of menstrual blood is 3 days or less, whereas for a few its duration is more than 5 days per menstrual cycle. Among the sample women, as high as 77 per cent mentioned that the flow of menstrual blood is at an average level. On the other hand, one-sixth of them felt that the intensity of blood flow during menstruation is very little and another one-tenth of them stated that such incomplete flow is severe for them. A large percent of them (75\%) reported that they did not felt any difference in menstruation after marriage. On the other hand, some stated 'discomfort in the abdomen is reduced', severity of blooding is decreased and use to get regular menstrual periods', whereas some other reported that there is an increase in 'discomfort in the abdomen' and 'severity of blooding'.

\begin{tabular}{|c|c|c|}
\hline Menstruation and Related Aspects & Percentage & Number \\
\hline $\begin{array}{cl}2.1 & \text { Age at First Menstruation (in Years) } \\
11 \\
12 \\
13 \\
14 \\
15\end{array}$ & $\begin{array}{l}2.8 \\
20.3 \\
38.0 \\
30.8 \\
8.3\end{array}$ & $\begin{array}{l}11 \\
81 \\
152 \\
123 \\
33\end{array}$ \\
\hline $\begin{array}{l}\text { 2.2 Knowledge about Menstruation } \\
\text { Shedding of Blood from Vagina on } \\
\text { Regular Intervals } \\
\text { Indicates that Woman is Eligible for } \\
\text { Reproduction } \\
\text { It is a Normal Process or Phenomenon }\end{array}$ & $\begin{array}{l}49.3 \\
11.5 \\
39.3\end{array}$ & $\begin{array}{l}197 \\
46 \\
157\end{array}$ \\
\hline $\begin{array}{l}\text { 2.3 Local Name for Menstruation } \\
\text { Mensus } \\
\text { Date } \\
\text { Muttu } \\
\text { Periods } \\
\text { Bahistu }\end{array}$ & $\begin{array}{l}36.3 \\
21.3 \\
29.5 \\
4.5 \\
8.5\end{array}$ & $\begin{array}{l}145 \\
85 \\
118 \\
18 \\
34\end{array}$ \\
\hline $\begin{array}{l}\text { 2.4 Sources of Information about } \\
\text { Menstruation } \\
\text { No Response } \\
\text { Class Text Books / Teacher } \\
\text { Magazines / friends } \\
\text { Mother / Sister and Other Elders } \\
\text { Mass Media }\end{array}$ & $\begin{array}{l}19.5 \\
13.8 \\
30.8 \\
31.5 \\
4.5\end{array}$ & $\begin{array}{l}78 \\
55 \\
123 \\
126 \\
18\end{array}$ \\
\hline $\begin{array}{l}\text { 2.5 Anybody explained about Menstruation } \\
\text { No } \\
\text { Yes }\end{array}$ & $\begin{array}{l}70.8 \\
29.2\end{array}$ & $\begin{array}{l}283 \\
117\end{array}$ \\
\hline $\begin{array}{l}\text { 2.6 Reaction about First Menstruation } \\
\text { Informed to Mother } \\
\text { Frightened } \\
\text { Felt Dirty } \\
\text { Concealed from Others }\end{array}$ & $\begin{array}{l}74.8 \\
20.0 \\
4.0 \\
1.3\end{array}$ & $\begin{array}{l}299 \\
80 \\
16 \\
5\end{array}$ \\
\hline $\begin{array}{l}\text { 2.7 Regularity of Menstrual Cycle } \\
\text { Regular } \\
\text { Irregular } \\
\end{array}$ & $\begin{array}{l}76.0 \\
24.0 \\
\end{array}$ & $\begin{array}{l}304 \\
96 \\
\end{array}$ \\
\hline $\begin{array}{l}2.8 \text { Length of Menstrual Cycle } \\
<25 \text { days } \\
25 \text { - } 28 \text { days } \\
29 \text { - } 30 \text { days } \\
>30 \text { days }\end{array}$ & $\begin{array}{l}5.8 \\
53.0 \\
35.3 \\
6.0\end{array}$ & $\begin{array}{l}23 \\
212 \\
141 \\
24\end{array}$ \\
\hline $\begin{array}{l}\text { 2.9 Duration of Menstrual Bleeding } \\
\text { <3 days } \\
4 \text { days } \\
5 \text { days } \\
6 \text { + days }\end{array}$ & $\begin{array}{l}11.3 \\
39.8 \\
41.5 \\
7.5\end{array}$ & $\begin{array}{l}45 \\
159 \\
166 \\
30\end{array}$ \\
\hline $\begin{array}{l}\text { 2.10 Intensity of Menstrual Bleeding } \\
\text { Very Little } \\
\text { Average }\end{array}$ & $\begin{array}{l}14.3 \\
76.8\end{array}$ & $\begin{array}{l}57 \\
307\end{array}$ \\
\hline
\end{tabular}




\begin{tabular}{||l|l|l||}
\hline Severe & 9.0 & 36 \\
\hline 2.11 Observed Differences in Menstruation & & \\
after Marriage & & \\
& 75.0 & 300 \\
No Difference Observed in Menstruation & 8.8 & 35 \\
Discomfort in the Abdomen is Reduced & 5.8 & 23 \\
Discomfort in the Abdomen is Increased & 3.8 & 15 \\
Severity of Blooding is Increased & 4.0 & 16 \\
Severity of blooding is decreased & 2.8 & 11 \\
Getting Regular Menstrual Periods & $\mathbf{1 0 0 . 0}$ \\
\hline Total & $\mathbf{4 0 0}$ \\
\hline TABLE 2: Percentage Distribution of the Respondents by their Menstruation and Related Aspects \\
\hline
\end{tabular}

\section{Menstrual hygiene}

3.1 Frequency of cleaning of perineum during menstruation: slightly less than three-fifths (58.5\%) used to clean the perineum during menstruation after each and every urination and or defecation, whereas a sizeable proportion of them (18.3\%) use to do such cleaning morning and evening and whenever feel-like. Few of them (6.2\%) reported that they would clean the perineum while taking bath only thus, appear to be least bothered about their personal hygiene during menstruation.

3.2 Material used to clean the perineum: slightly more than half of them $(51.5 \%)$ stated that they use to clean the perineum during menstruation with cold water only, wherein the possibility of infection occurs. On the other hand, about two-fifths of them (36.2\%) use to clean the perineum with the help of soap and hot or cold water, which appears to be a better health practice, whereas one one-tenth of them use hot water only for such practice. 3.3 Method of cleaning the perineum: slightly more than half of them $(52 \%)$ stated that they use to clean perineum by both washing from front to back and back to front. A substantial proportion of them (37.8\%) reported that they use to wash perineum from front to back, whereas one-tenth uses to wash perineum from back to front only.

3.4 Material used to clean hands: a large per cent $(58.8 \%)$ use soap and hot/cold water for washing hands after cleaning the perineum during menstruation, which can be stated as a hygienic practice. On the other hand, more than one-fourth of them $(28.2 \%)$ use to do such practice with the help of cold water alone and the remaining of them stated that they use hot water for such purpose.

3.5 Type of perineal pads used: a greater proportion of the respondents (77.5\%) used clean old cotton cloth as perineal pads, whereas about one-fifth of them (20.5\%) using sanitary napkins available in the market. Only 8 women reported to be using underskirt as perineal pads.

3.6 Method of taking care of Perineal Cloth Pads: An overwhelming percent (84.6\%) stated that they use to wash it with soap/water and dry it under sunlight, whereas some reported that they use to wash with water alone and dry. Rest few reported that they use to give to dhobi for washing by paying extra money.

3.7 Frequency of Changing the Perineal Pads: It is conspicuous to note that an overwhelming proportion of respondents $(87 \%)$ have developed the habit of changing the cloth whenever it is soaked (and/or if they feel discomfort), which is a hygienic practices. While slightly less than one-tenth of the respondents used to change the menstrual pad only once i.e., during bath, few of them change such pads before going to bed and early in the morning (at least two times).

3.8 Disposal of Perineal Pads after use: Most of the women simply throw it away at the place of defecation. Among the sample respondents, about half of them (50\%) stated that they use to wash and reuse for several times and after that they use to simply throw at open place, generally a specified places, which are mostly meant for open field defecation for women,. On the other hand, it is interesting to note that slightly more than onefourth of them burnt the menstrual pads after their use, whereas about 22 per cent of them use to throw them in dust bin, which would be later dumped into a pit and/or directly thrown into a pit and cover it with soil.

3.9 Menstrual Hygiene: In the present study, in order to understand the overall menstrual hygiene of the married adolescents and young women, an index has been constructed by pooling the scores assigned to the responses elicited to various individual healthy practices followed during menstruation. Based on the cumulative scores of the menstrual hygiene for each adolescent girl, all of them have been categorized into three groups, which are arbitrary and would indicate roughly the level of menstrual healthy practices they follow, 'poor', 'fair' and 'good'. A simple majority of the respondents are stated to be under 'poor' menstrual hygiene category closely followed by 'fair' menstrual hygienic practices. It is conspicuous to note that slightly more than one-fifth appears to be adhering to 'good' menstrual hygiene. The overall level of menstrual hygiene is just above average among the sample respondents. 


\begin{tabular}{|c|c|c|}
\hline Menstrual Hygiene Practices & Percentage & Number \\
\hline $\begin{array}{l}\text { 3.1 Frequency of Cleaning of Perineal } \\
\text { during Menstruation } \\
\text { While taking bath alone } \\
\text { After Voiding Urine and Defecation } \\
\text { Morning and Evening } \\
\text { Whenever feel - like }\end{array}$ & $\begin{array}{l}6.2 \\
58.5 \\
18.3 \\
17.0\end{array}$ & $\begin{array}{l}25 \\
234 \\
73 \\
68\end{array}$ \\
\hline $\begin{array}{l}\text { 3.2 Material Used to Clean the Perineum } \\
\text { Cold Water alone } \\
\text { Hot Water alone } \\
\text { Soap and Cold / Hot Water } \\
\text { Medicated Water }\end{array}$ & $\begin{array}{l}51.5 \\
10.8 \\
36.2 \\
1.5\end{array}$ & $\begin{array}{l}206 \\
43 \\
145 \\
6\end{array}$ \\
\hline $\begin{array}{l}\text { 3.3 Method of Cleaning the Perineum } \\
\text { Wash from Front to Back } \\
\text { Wash from Back to Front } \\
\text { Both }\end{array}$ & $\begin{array}{l}37.8 \\
10.2 \\
52.0 \\
\end{array}$ & $\begin{array}{l}151 \\
41 \\
208 \\
\end{array}$ \\
\hline $\begin{array}{l}\text { 3.4 Material Used to Clean Hands } \\
\text { Cold Water alone } \\
\text { Hot Water alone } \\
\text { Soap and Hot / Cold Water }\end{array}$ & $\begin{array}{l}28.2 \\
13.0 \\
58.8\end{array}$ & $\begin{array}{l}113 \\
52 \\
235\end{array}$ \\
\hline $\begin{array}{l}\text { 3.5 Type of Perineum Pads Used } \\
\text { Clean Old Cotton } \\
\text { Under Skirt } \\
\text { Ready Made Commercial Pads }\end{array}$ & $\begin{array}{l}77.5 \\
2.0 \\
20.5\end{array}$ & $\begin{array}{l}310 \\
8 \\
82 \\
\end{array}$ \\
\hline $\begin{array}{l}\text { 3.6 Method of Taking Care of Perineal } \\
\text { Cloth Pad" } \\
\text { Wash with soap and water/ } \\
\text { dry it under sunlight } \\
\text { Wash with water alone and dry } \\
\text { Give to the dhobi }\end{array}$ & $\begin{array}{l}84.6 \\
12.3 \\
3.1\end{array}$ & $\begin{array}{l}269 \\
39 \\
10\end{array}$ \\
\hline $\begin{array}{l}\text { 3.7 Frequency of Changing the Pad } \\
\text { Whenever the pad is soaked } \\
\text { Before going to bed early in the morning } \\
\text { Only once during bath }\end{array}$ & $\begin{array}{l}87.0 \\
4.0 \\
9.0\end{array}$ & $\begin{array}{l}348 \\
16 \\
36 \\
\end{array}$ \\
\hline $\begin{array}{l}\text { 3.8 Disposal of Perineal Pads after Use } \\
\text { Thrown in dust bin } \\
\text { Burn it } \\
\text { Wash and reuse, and throw it } \\
\end{array}$ & $\begin{array}{l}22.3 \\
27.8 \\
50.0\end{array}$ & $\begin{array}{l}89 \\
111 \\
200\end{array}$ \\
\hline $\begin{array}{l}\text { 3.9 Menstrual Hygiene (Index) } \\
\text { Poor (Scores } 3-7) \\
\text { Fair (Scores } 8-9) \\
\text { Good (Scores } 10-13)\end{array}$ & $\begin{array}{l}37.5 \\
36.3 \\
26.2\end{array}$ & $\begin{array}{l}150 \\
145 \\
105\end{array}$ \\
\hline Total & 100.0 & 400 \\
\hline
\end{tabular}

\section{Food and social restrictions during menstruation}

4.1 Foods avoided during menstruation: It is evident that among the sample women, two-fifths of them (40.2\%) used to avoid curd/butter followed by papaya (25.8\%) and others like sweets, brinjal, ghee, etc., curiously, slightly less than one-fifth of women (18.5\%) stated that they did not avoid taking any specific food during the days of menstruation.

4.2 Reasons for avoiding foods: Slightly less than one-third of them (332.8\%) reported that by taking such foods 'causes more bleeding' during menstruation closely followed by 'causes smell' and a few (5.8\%) stated that eating such foods would 'causes allergy/indigestion'. Interestingly, about one-fifth of them didn't know the reason for avoiding some foods during menstruation, whereas some (11.1\%) reported that it is mainly because of custom.

4.3 Special foods taken during menstruation: among the sample respondents as high as 64 per cent did not take any special foods during menstruation. On the other hand, about one-sixth of them use to take 'dhal/pulses' more, followed by Nuvvulu (oil seeds) and spicy foods. Very few stated that they use to take more fluids and fruits during the days of menstruation.

4.4 Reasons for Taking Special Foods: a large majority (57.1\%) reported that by taking such foods would give more strength and about 15 percent stated that they do so because of custom. Curiously, about one-third of them (32.4\%) told that they didn't know the exact reason for taking special foods during menstruation.

4.5 Selected Restrictions during Menstruation: a greater proportion of them (63.5\%) stated they use to restrict themselves in participating sexual activities and selected social activities like, entering pooja room, going to temple, social functions like marriage, naming ceremony, etc. On the other hand, about 37 per cent sated that they use restrict themselves in participating in usual day-to-day activities such as working at home, cooking 
food, bringing drinking water, touching stored foods, utensils, washing clothes, etc. Interestingly, more than half of them stated that they use of take additional rest during menstruation. By and large, women by restricting to participate in all these activities indirectly encourage them to hygienic way of living during menstruation.

4.6 Restrictions during Menstruation (Index): In order to have a composite index, scores have been assigned to categories of restrictions discussed in the preceding lines and the pooled scores for each of the respondents considered here as an Index of restrictions followed during menstruation. Among the total sample, most of them categorized as adhering to less restrictions during menstruation, whereas the remaining to more restrictions

\begin{tabular}{|c|c|c|}
\hline Food and restrictions during menstruation. & Percentage & Number \\
\hline $\begin{array}{l}\text { 4.1 Foods Avoided during Menstruation } \\
\text { Not Avoided any Food } \\
\text { Curd /Butter } \\
\text { Papaya } \\
\text { Others (Sweets, Brinjal, Ghee) }\end{array}$ & $\begin{array}{l}18.5 \\
40.2 \\
25.8 \\
15.5\end{array}$ & $\begin{array}{l}74 \\
161 \\
103 \\
62\end{array}$ \\
\hline $\begin{array}{l}\text { 4.2 Reasons for Avoiding Foods } \\
\text { Don't Know } \\
\text { Causes Bleeding } \\
\text { Causes Smell } \\
\text { Causes Allergy / Indigestion } \\
\text { Custom }\end{array}$ & $\begin{array}{l}19.9 \\
32.8 \\
30.4 \\
5.8 \\
11.1\end{array}$ & $\begin{array}{l}65 \\
107 \\
99 \\
19 \\
36\end{array}$ \\
\hline $\begin{array}{l}\text { 4.3 Special Foods Taken during Menstruation } \\
\text { Not Taken any Special Foods } \\
\text { Dhal and Pulses } \\
\text { Spicy Food } \\
\text { More Fluids } \\
\text { Nuvvulu } \\
\text { Fruits }\end{array}$ & $\begin{array}{l}63.7 \\
16.3 \\
6.5 \\
3.5 \\
7.8 \\
2.2\end{array}$ & $\begin{array}{l}255 \\
65 \\
26 \\
14 \\
31 \\
9\end{array}$ \\
\hline $\begin{array}{l}\text { 4.4 Reasons for Taking Special Foods* } \\
\text { Don't Know } \\
\text { For Strength } \\
\text { Custom } \\
\end{array}$ & $\begin{array}{l}32.4 \\
57.1 \\
14.5\end{array}$ & $\begin{array}{l}47 \\
75 \\
23\end{array}$ \\
\hline $\begin{array}{l}\text { 4.5 Restriction for Usual Activities } \\
\text { No } \\
\text { Yes }\end{array}$ & $\begin{array}{l}63.5 \\
36.5 \\
\end{array}$ & $\begin{array}{l}254 \\
146\end{array}$ \\
\hline $\begin{array}{l}\text { 4.6 Takes Additional Rest } \\
\text { No } \\
\text { Yes }\end{array}$ & $\begin{array}{l}44.5 \\
55.5\end{array}$ & $\begin{array}{l}178 \\
222\end{array}$ \\
\hline $\begin{array}{l}\text { 4.7 Follows Social Restriction } \\
\text { No } \\
\text { Yes }\end{array}$ & $\begin{array}{l}37.8 \\
62.2\end{array}$ & $\begin{array}{l}151 \\
249\end{array}$ \\
\hline $\begin{array}{l}\text { 4.8 Participates in Sexual Activities } \\
\text { No } \\
\text { Yes }\end{array}$ & $\begin{array}{l}88.8 \\
11.2\end{array}$ & $\begin{array}{l}355 \\
45\end{array}$ \\
\hline $\begin{array}{l}\text { 4.9 Restrictions During Menstruation (Index) } \\
\text { Low (Scores 0-1) } \\
\text { High (Scores 2-4) }\end{array}$ & $\begin{array}{l}51.3 \\
48.8\end{array}$ & $\begin{array}{l}205 \\
195\end{array}$ \\
\hline Total & 100.0 & 400 \\
\hline
\end{tabular}

\section{Discussion}

Mean scores of respondents' menstrual hygiene is observed to be significantly ( $\mathrm{p}<0.001$ ) very high among those who belong to nuclear families than among those from joint families. It is interesting to note that the average scores of menstrual hygiene are found to be very high among those respondents who are educated up to middle school and above than their counterparts who have little education and no education, i.e., illiterates. Similar pattern in menstrual hygiene of the respondents across spouses' level of education is also worth to be noted. It is further, conspicuous to note that the differences in mean scores of menstrual hygiene across respondents' and spouses' level of educational attainment turn out to be highly significant $(\mathrm{p}<0.01$ and $\mathrm{p}<0.01$, respectively).

It is curious to note that the mean score of menstrual hygiene of working women is comparatively lower, than their non-working counterparts. Menstrual hygiene of respondents is found to be reasonably higher among those whose spouses are employees closely followed by cultivators / engaged in petty business / skilled / semi-skilled workers than those working as agricultural labourers and the ANOVA results also observed to be highly significant $(\mathrm{p}<0.01)$.

Level of menstrual hygiene appear to be increasing (significant at moderate level; $\mathrm{p}<0.05$ ) with an increase in time spent on watching TV / listening to radio. It is also interesting to note that the average level of 
menstrual hygiene of those respondents who married their blood relatives is found to be higher (and moderately significant; $\mathrm{p}<0.05$ ) than those who married with non-blood relatives. Differentials in mean scores of menstrual hygiene across the categories of knowledge about menstruation are tiny.

It is fascinating to note that the average score of menstrual hygiene is comparatively higher among those respondents who had been explained about menstruation by anybody those who did not had such opportunity. The mean scores also turned out to be highly significant $(\mathrm{p}<0.001)$. Another fascinating fact noted here is that the mean scores of menstrual hygiene are moderately higher (and significant at 0.05 level) among those respondents for whom 'Class Text Books/Teachers/Mothers/Elders' are major sources of information about menstruation before its first experience closely followed by 'Mass Media/Magazines/Friends' as against those who do not known about such experience before its occurrence. On the other hand, the mean score of menstrual hygiene appear to be marginally lower among those who are adhering to large number of restrictions during menstruation than those who are following small number of such restrictions.

\section{DETERMINANTS OF MENSTRUAL HYGIENE (INDEX)}

The menstrual hygiene index shows that nuclear family tends to increases the respondents' level of menstrual hygiene to a greater extent $(\mathrm{p}<0.10)$ than that of joint family. Next to this, it is conspicuous to note that young women's age at marriage and occupational status of spouses have exhibited significant positive net effects $(p<0.01$ in each case) on their menstrual hygiene practices indicating that an increase in age at marriage of the respondents and spouse's occupation status would result into an increase in the overall level of menstrual hygiene of respondents.

\begin{tabular}{||l|l|c||}
\hline \hline Explanatory Variables & $\begin{array}{l}\text { Beta } \\
\text { Coefficients }\end{array}$ & t-values \\
\hline Age of the Respondent & -0.041 & -0.628 \\
Age at marriage of the Respondent & 0.161 & $2.507^{* *}$ \\
Caste Background & -0.110 & $-2.261^{*}$ \\
Place of Birth (Urban) & 0.035 & 0.694 \\
Type of Family (Nuclear Family) & 0.173 & $3.565^{* * *}$ \\
Education of the Respondent & -0.024 & -0.452 \\
Education of the Spouse & 0.001 & 0.024 \\
Occupation of the Respondent & -0.048 & -0.982 \\
Occupation of the Spouse & 0.143 & $2.627^{* *}$ \\
Time Spent for Watching TV/ & 0.075 & 1.521 \\
$\quad$ Listening Radio & 0.086 & $1.793^{+}$ \\
Marriage with a Blood Relative (Yes) & 0.121 & $2.299^{*}$ \\
Anybody Explained about Menstruation (Yes) & 0.114 & $2.159^{*}$ \\
Sources of Information for Menstruation & & \\
$\quad$ before its First Experience & -0.093 & $-1.960^{*}$ \\
\hline Restrictions During Menstruation (Index) & $\mathbf{1 7 . 1}$ (400) & \\
\hline $\mathbf{R}^{\mathbf{2}}$ (N) & \multicolumn{2}{||}{} \\
\hline TABLE : 5 Results of Multiple Regression Analysis on Respondents' Menstrual Hygiene \\
\hline \hline
\end{tabular}

Curiously, young married women who got explanation about menstruation by anybody, who learnt about menstruation from multiple sources, and who married blood relatives are more likely to practice menstrual hygiene to a moderately higher extent $(\mathrm{p}<0.05, \mathrm{p}<0.05$ and $\mathrm{p}<0.10$, respectively) that their counterparts. Rest of the variables used in the model though demonstrated expected sign of net effects on respondents' overall level of menstrual hygiene controlling for other variables, their magnitude of effects did not turn out to be significant.

\section{Conclussion}

Among reproductive health issues, menstruation and its hygiene are neglected and young women to have accurate and adequate information about menstruation and its management. The medical health care personnel have to organize village level/urban slum level meetings/camps to interact with married adolescent and young women to increase their awareness on menstrual hygiene. Most of the adolescent and young women were not consumed balanced diet due to food restrictions and taboos during menstruation. Hence, it is suggested to conduct extensive nutrition educational programmes along with health education by the health functionaries. Due to economical constrains most of the married adolescence / young women could not offered to purchase napkins to use during menstruation. Hence, locally made sanitary napkins may be provided at cheaper rate. The 
production of sanitary napkin can be taken up by women self help groups as a part of their income generation programme besides women/adolescent girls should be made aware to use old cloth hygienically

\section{References}

[1]. Ahuja A, Tiwari S (1995). Awareness about pubertal changes among adolescent girls. Journal of Family Welfare; 41(1):46-50.

[2]. Deo DS and Ghattargi CH (2005) Perceptions and Practices Regarding Menstruation: A comparative Study in Urban and Rural Adolescent Girls. Indian Journal of Community Medicine. Jan-Mar (30):1

[3]. Indian Council of Medical Research (I.C.M.R). (2005-2006). Knowledge and Practices of adolescent girls. In Reproductive health. ICMR annual report, New Delhi, 74. Available at: http.//www.icmr.nic.in/annual/2005-06/hqds/rh.pdf.

[4]. Jyothi Kamalam K, Rajalakshmi B (2005) Reproductive Health Awareness among College-Going Girls: Indian Journal of Social Work. 66(4):414-430

[5]. Khanna A, Goyal RS, Bhawsar R (2005). Menstrual practices and reproductive problems: A study of adolescent girls in Rajasthan. Journal of Health Management. 7(1):91-97.

[6]. Nair Parvathy, Grover L Vijay (2007). Awareness and practices of menstruation and pubertal changes amongst unmarried female adolescent in a rural area of East Delhi:Indian Journal of Community Medicine. 32(2):156-157. 